\title{
球状水結晶中の硫酸イオンの濃度分布と溶出現象
}

\author{
山口 東吾, 田口 洋治, 加藤 皓一 \\ 新潟大学「学部化学システムエ、学科（†950-21 新潟市五十嵐 2 の町8050).
}

[平成 8 年 4 月 5 日受理］

\section{Distribution of Sulfate Ions in Spherical Ice Crystals and Elution Phenomena}

\author{
Togo YAMAGUCHI, Yoji TAGUCHI and Koichi KATOH \\ Department of Chemistry and Chemical Engineering, Faculty of Engineering, Niigata University \\ (8050 Ikarashi 2-nocho, Niigata 950-21) \\ [Received April 5, 1996]
}

\begin{abstract}
Summary
There is a remarkable tendency for the hydrogen ion concentration in snowmelt water in the early spring to be higher than that in the late spring. Falling fresh snow catches atmospheric acid substances in the atmosphere. The fresh fallen snow on the ground is compressed by repeated dissolution and crystallization and forms icy granular snow. The repetition causes sulfate, nitrate and chloride ions to be concentrated near the surface of the icy granular snow. Some laboratory experiments were performed to examine this concentration phenomenon by the formation of spherical ice crystallized from sulfate-containing water and by dissolution of the formed ice crystals.

On dissolution, the inclusion amount and the distribution of sulfate ions in ice crystals were measured. The distribution of sulfate in the crystals was found to be biased; the sulfate amount near the surface was larger than that around the center, when each crystal was melted from the surface to the center in organic solvent. It was also found that the higher initial concentration of sulfate tended to create a uniform distribution of sulfate.

When the ice crystals were packed in a column $(2.0 \mathrm{~cm}$ inner diameter, $30 \mathrm{~cm}$ length) and dissolved at room temperature, a higher concentration of sulfate was observed in the first effluent. The concentration ratio was higher than the estimated value at the surface using the organic solvent method. With the dissolution of the natural granular snow, similar results were obtained; higher concentrations of sulfate ions were observed in the first effluent and lower concentrations in the later effluent.
\end{abstract}

Key words: sulfate ions, acid snow, snowmelt water, granular snow, spherical ice crystals

\section{1.はじめに}

雪は降雪後, 溶解・再結晶を繰り返し, 粒径の大きい ザラメ雪の状態で春を迎える。最初の雪解け水中の水素
イオン濃度は高く, 降雪時に雪が空気中の酸性物質を捕

捉し, 融雪時に優先的に解け出ると言われている

本研究では, 主として硫酸イオンを含む球形の水結晶 を生成し，それらを三つの異なる方法で溶解し，硫酸イ 
オンの溶出現象を実験室的に再現し, 溶出イオン濃度を 比較検討し, 何故最初に溶け出てくる雪解け水中のイオ ン濃度が高くなるのかを考察した。また, 天然のザラメ 雪を採取し，それらを実験室で溶解し，氷結晶の場合の 溶出現象と比較検討した。

\section{2. 実験装置及び方法}

\section{1 水結晶の生成方法}

球形の氷結晶を次の二つの方法により生成した。一つ は, 球形の氷を市販の製水器を用いて冷凍庫中で, 約 6 時間かけて生成した。後に述べる直径 $18 \mathrm{~mm}$ の水結晶は, この方法で生成した。二つ目の方法は，Fig. 1 に示した

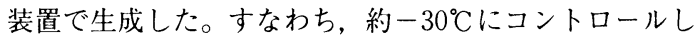
たジエチルエーテルの入ったカラム中で，硫酸イオンを 含む水溶液をノズルを通して液滴を生成し，それを自然 落下させ，カラム底に到達するまでに凍らせ，硫酸イオ ンを含む氷結晶を生成した。この方法は，先の方法と比 較して, 水溶液は急激に冷却され短時間に水結晶が生成 される。後述の直径 $3.5 \mathrm{~mm}$ の水結晶はこの方法で生成 した。硫酸イオンを含む溶液は, 純正化学社製の特級試 薬の硫酸カリウムを用いて適宜所定の濃度に調製した。

一部の実験で用いた硝酸カリウムと塩化カリウム溶液も 純正化学社製の特級試薬から調製した。

\section{2 氷結晶の溶解方法}

生成した氷結晶を Fig. 2 に示す A，B，C法の三つの 方法で溶解した。A 法では, ガラス製円筒容器（直径 $20 \mathrm{~mm}$, 長さ $30 \mathrm{~cm})$ 内に, $18 \mathrm{~mm}$ の水結晶は縦一列に, $3.5 \mathrm{~mm}$ の水結晶の場合はランダムにそれぞれ充填し溶 解した。円筒容器は予め冷蔵庫で泠却した後水結晶を允 填した。B法では，18mm の水結晶に対しては平面状に 隙間なく並べ， $3.5 \mathrm{~mm}$ の氷結晶は平面状に数層に重ね て溶解した。 A， B 法ともに下部からの溶出液をフラク ションコレクターで全て分取しサンプルとした。C法で は, 承結晶を有機溶媒 (ジエチルエーテル)の入ったコッ ク付ガラス容器内で摚拌しながら溶解し，下のコックか ら溶解液を一定時間毎に分取しサンプルとした。溶解は 全て室温で行った。サンプル中のイオン濃度はイオンク ロマトグラフ法または吸光光度法3)で測定した。

\section{3. 実験結果及び考察}

\section{1 三つの溶解方法による筤度变化}

溶解方法 (A， B， C 法) の違いによる溶出液中の濃 度変化を初濃度 $1000 \mathrm{mg} / \ell$ の硫酸イオン溶液から生成し た直径 $3.5 \mathrm{~mm}$ の水結晶を用いて調べ, Fig. 3 に示した。 横軸は，氷結晶生成に要した全液量から一つの見かけの 球を想定した半径 $\mathrm{R}$ と, 溶解した液量から求めた半径 $\mathrm{r}$ との比である。縦軸は, 水結晶の生成に用いた溶液の初

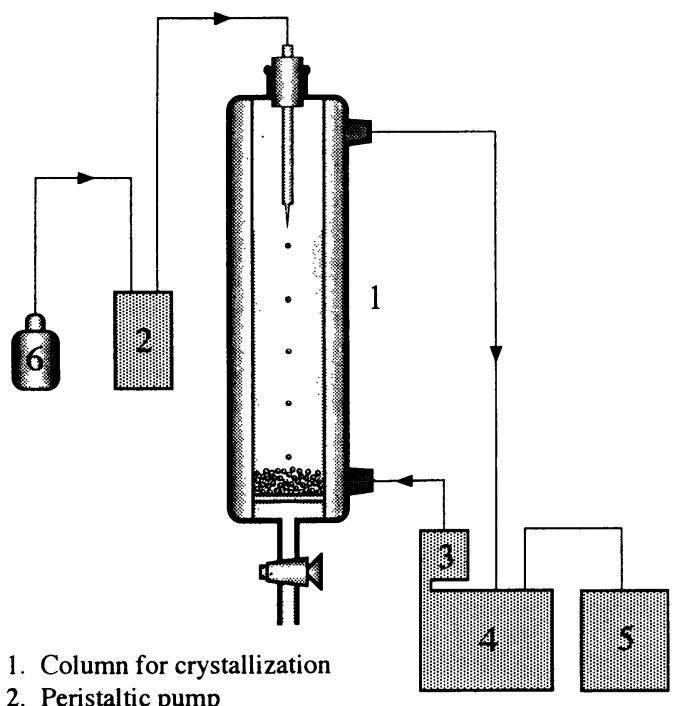

2. Peristaltic pump

3. Temperature control unit with a circulating pump 5. Cool-pipe

4. Constant temperature bath 6. Sulfate-contg. solution

Fig. 1 Experimental apparatus for freezing
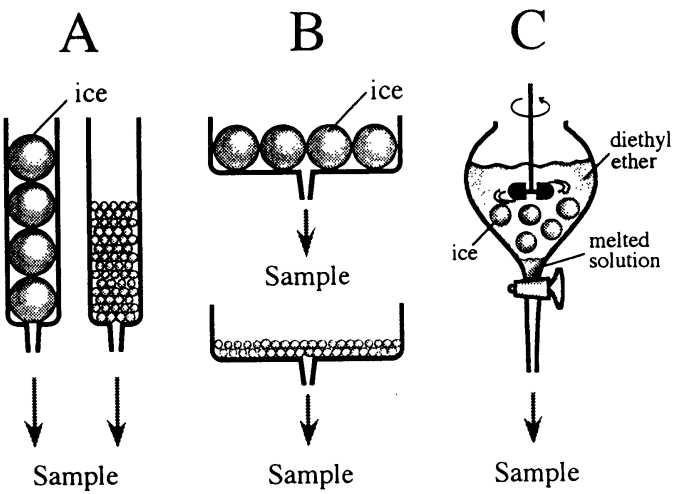

Fig. 2 Melting methods

濃度 $\mathrm{C}_{0}$ に対するサンプル濃度 C との比である。A 法に よる溶解では，濃度変化は一番顕著に現れ，球表面の最 も近い位置に濃度比のピークがあり中心ほど低くなって いる。四には示してないがB 法では，大きな濃度变化 は見らず， $r / R=0.8$ 付近にそのピークが存在した。C法 では， $r / R=0.9 の$ 表面付近にピークが見られ，中心に 向かうにつれ一定值に近づいた。この方法では，個々の 水結晶はほぼ均一に球表面から溶解し，その溶解液を开 ンプリングしていることから，この曲線は個々の水結晶 中の硫酸イオンの濃度分布をより忠実に表現していると 思われる。A，C法による濃度曲線の相違は興味深い。

同様に, 初濃度 $100 \mathrm{mg} / \ell$ の硫酸イオン溶液から生成 


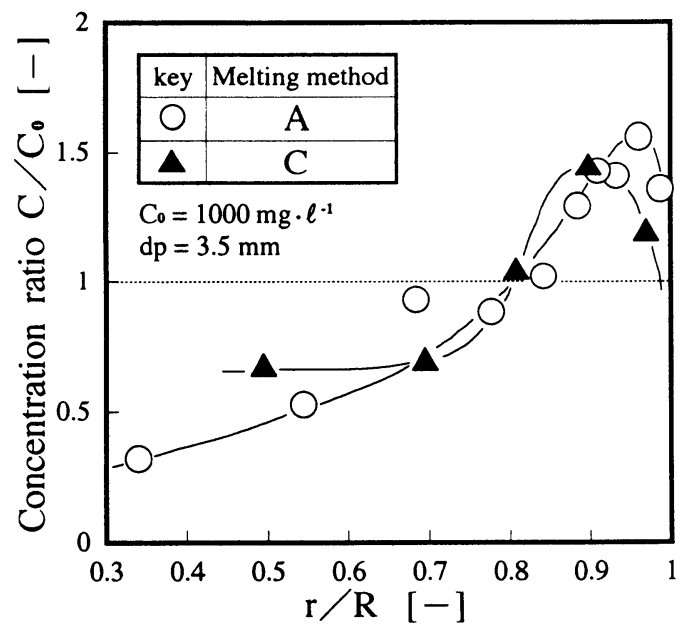

Fig. 3 Comparison of distributions of sulfate obtained by methods $\mathrm{A}$ and $\mathrm{C}$

した直径18mm の水結晶を用いて比較した例をFig. 4 に 示した。 $\mathrm{A}, \mathrm{B}$ 法では, 見かけの球の表面付近ほど濃度 比は高く, 中心方向に向かい低くなった。眓には示して ないが B 法では, 球状水結晶が主に下部の接触面付近 から溶解が進み, 半球状になり徐々に消滅していくため, 戸外での雪解け現象とやや異なると判断した。C 法では, 表面付近で濃度比が高く, 中心に向かうにつれ一旦減少 し, その後徐々に増加した。この方法では, 直径 $3.5 \mathrm{~mm}$ の場合と同様, 個々の水結晶はほほ均一に表面から溶解 し，その溶解液をサンプリングしていることから，この 方法で得た曲線は個々の水結晶中の硫酸イオンの濃度分 布を忠実に表現していると思われる。

\section{2 球形水結晶中の渾度分布}

C 法で硫酸イオンの初濃度による水結唱中の濃度分布 への影響を調べるために，濃度を10，100，1000， $10000 \mathrm{mg} / \ell$ に調製した水溶液から, 直径 $3.5 \mathrm{~mm}$ の氷結 晶を生成し、それらを溶解した結果をFig. 5 に示した。 初濃度が10, $100 \mathrm{mg} / \ell$ の場合, 表面付近で濃度は一番 高く, 中心方向に向かい低くなった。初濃度が1000, $10000 \mathrm{mg} / \ell$ と高くなるにつれ, 表面付近の濃度ピーク は中心方向に移行する傾向にあり，そのピーク高さは初 濃度が高いほど低くなり, 濃度は均一に近づいていくと 推定される。

この実験で用いた結晶は, 硫酸イオンを含まないイオ ン交換水から生成した水結晶でさえも不透明で, 細かい 多数の亀裂によって白く見えた。溶解は球表面から進行 するが, 同時に亀裂からも溶解していく様子か観察され た。氷の単結晶は, 水分子以外の不純物に対しては, き

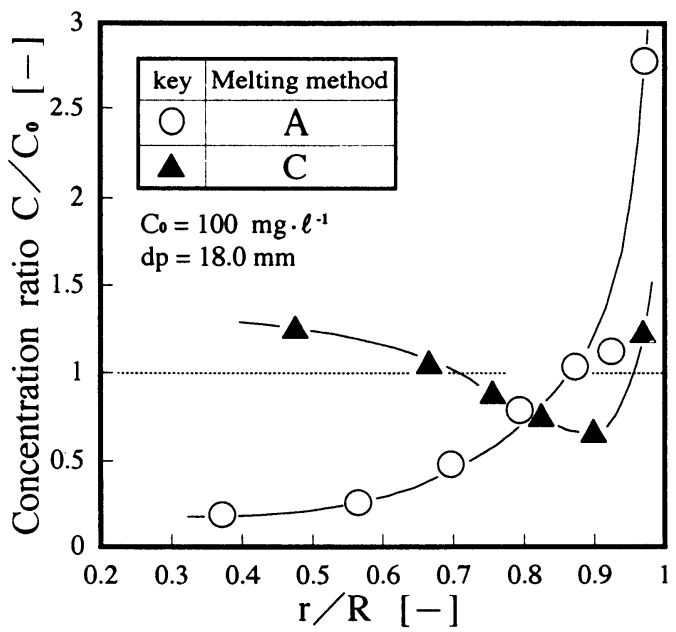

Fig. 4 Comparison of distributions of sulfate obtained by methods $\mathrm{A}$ and $\mathrm{C}$

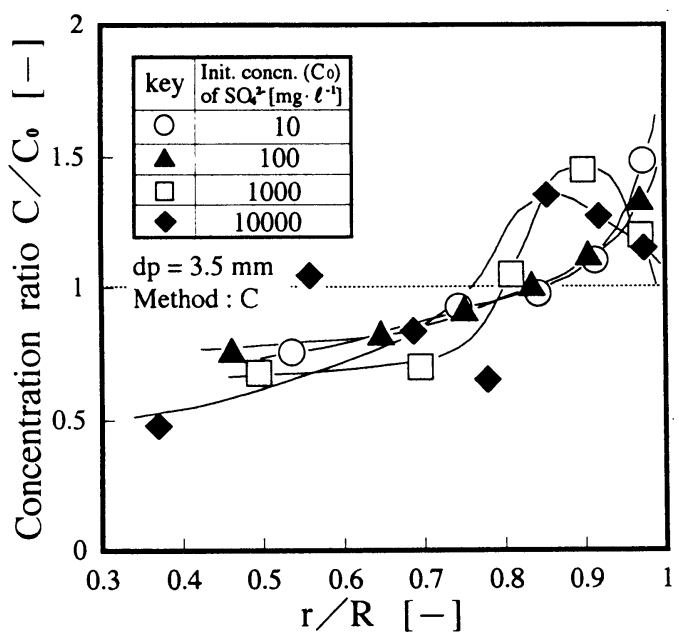

Fig. 5 Distribution of sulfate, dependence of initial concentration of sulfate ions

わめて排他的である4) と言われている。海水が涷る時, 塩分は氷の結晶内に入り込めず, 濃い塩水 (brine) となっ て吐き出され, 水が厚くなっても brine は液体のまま残 るという自然現象が観察されている5)。氷結晶中で硫酸 イオンがどのようにして取り込まれるのかは後述で考察 するが，急冷によって生成した場合，体積膨張などによ り多数の亀裂が生じ, その亀裂に濃縮された硫酸イオン が取り込まれ, 溶解時にその亀裂からも硫酸イオンが溶 出してくると考えられる。

同様に, 直径 $18 \mathrm{~mm}$ の氷結晶を用いた C 法による溶解 
実験結果をFig.6に示した。初濃度 100, 1000, $10000 \mathrm{mg} / \ell$ では, 濃度比は中心方向に向かい一旦減少

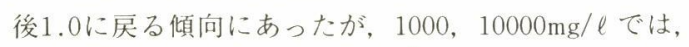
大きな濃度変化は見られず, 初濃度が高いほど均一な濃 度分布になる傾向が認められた。初濃度が $10 \mathrm{mg} / \ell$ の場 合, 表面付近で濃度が高く, 中心方向に向かうに従い減 少した。これらのことから初濃度が低い10ppm オーダー では, 濃度比からみて硫酸イオンは表面に多く偏在する と考えられる。

初濃度 $10,100,1000,10000 \mathrm{mg} / \ell$ の硫酸イオン溶液 から生成した直径 $18 \mathrm{~mm}$ の氷結晶の写真を Fig. 7 に示し た。初濃度が低いほどより透明で，高いほど白く不透明 であった。水結晶中に不純物が混入すると白くなること はすでに広く知られている 時の潜熱移動により生成した水蒸気の気泡と一部体積膨 張により生成した亀裂によるものと思われ，その領域は さらに水結晶にとって不純物である硫酸イオンの初濃度 が高いほど広くなると考えられる。

硫酸イオンの他に硝酸イオン, 塩化物イオンを同時に 含む水結晶中のそれぞれの濃度分布掞よび溶解現象につ いても検封した。硫酸, 硝酸, 塩化物イオンの三成分を 含む溶液から生成した直径 $18 \mathrm{~mm}$ の水結晶を用いて, C 法で溶解した結果の一例をFig. 8 に示した。水結晶生 成時の溶液の各イオンの初濃度は, 約 $100 \mu \mathrm{M}$ (汹中で は実測濃度の $\mathrm{ppm}$ で表示) になるよう調製した。各イ オンとも表面での濃度比は高く, 中心付近では低い結果 が得られた。詳練に見れば, 硫酸, 硝酸の唡イオンは, ほほ同一の濃度分布であるが，塩化物イオンは表面付近 で他の二成分よりもその濃度比はやや低く, 中心付近で

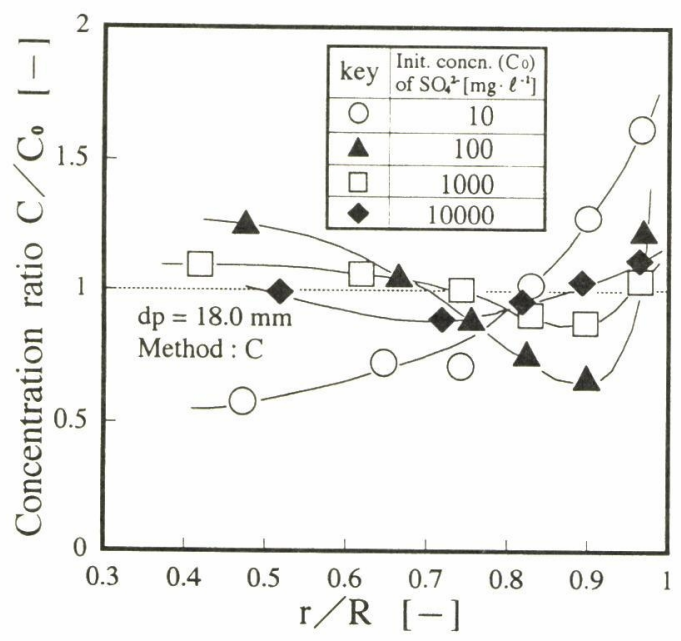

Fig. 6 Distribution of sulfate, dependence of initial concentration of sulfate ions
は高い。氷の結晶格子には大部分の不純物は人り迟めな いが,フッ素, アンモニア，塩素は例外的に組み込まれ ると言われて扣り ${ }^{4}$ ，本実験結果からもその傾向が窅え る。

\section{3 円筒容器内で溶解した場合の濃度变化}

自然の雪溶け現象に近い川筒状（A 法）での溶解を, 直径 $3.5 \mathrm{~mm}$ の水結昆を用い, 硫酸イオン濃度を 10,100 , $1000,10000 \mathrm{mg} / \ell$ と変えて実施した場仝の結果を Fig. 9 にホした。いずれの場余も見かけ上，表面付近で硫酸

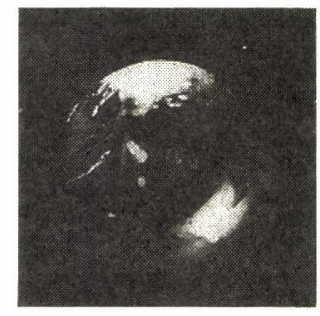

$\mathrm{C}_{0}=0 \mathrm{mg} \cdot \ell^{-1}$

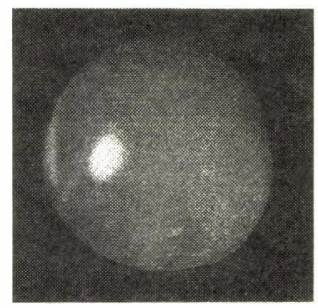

$\mathrm{C}_{0}=1000 \mathrm{mg} \cdot \ell^{-1}$
Fig. 7 Photograph of ice spheres $(\mathrm{dp}=18 \mathrm{~mm})$

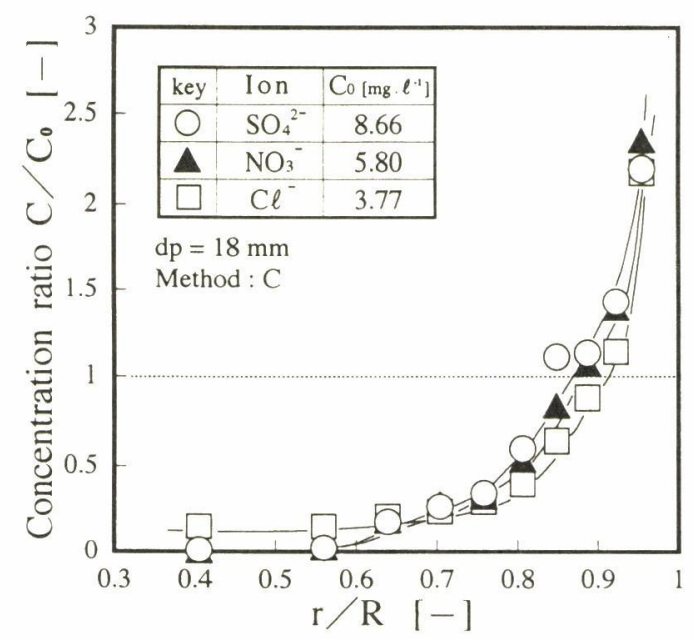

Fig. 8 Distributions of sulfate, nitrate and chloride ions 


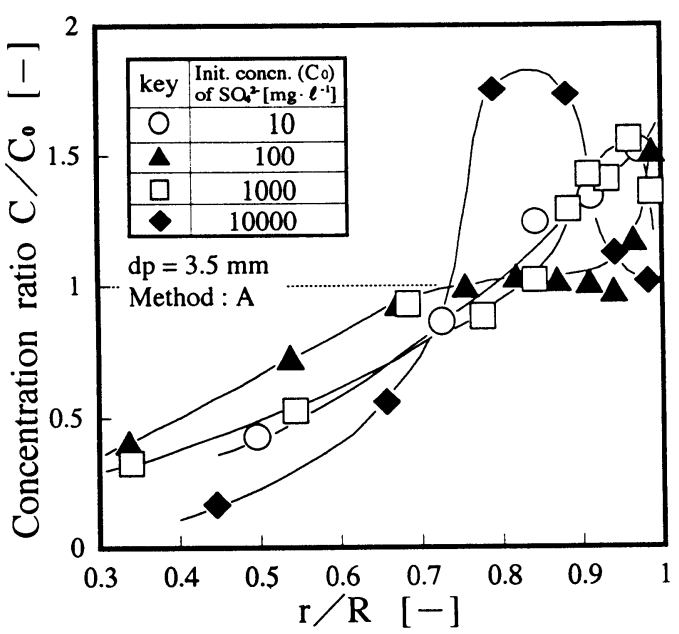

Fig. 9 Distribution of sulfate, dependence of initial concentration of sulfate ions

イオンの濃度比は高く, 中心付近では低い。初濃度が高 いと, C 法の場合の Fig. 5 で示した個々の水結晶の濃度 分布が比較的フラットであったのに対して，円筒状では このようによりシャープな分布になる理由は，溶解した 液が下の水結晶の表面に流れ落ち, 底部のサンプリング 口に到達するまでに溶解・再結晶を繰り返し濃縮が進む ものと考えられる。

自然界の雪解けは, 雪上面における太陽からの放射 (日 射), 大気放射, 雨または地熱によって加熱されて進むが, 積もった雪に供給される熱は, 主に日射と考えられる7)。 本実験では，上面からだけではなくカラム中の接触面か らも溶解することが観察された。主に上面から溶解して いく実際の雪解けでは, 本実験結果以上に溶解・再結晶 による濃縮が進むと推測される。

同一条件で直径 $18 \mathrm{~mm}$ の水結晶を用いて, 硫酸イオン 濃度を変えて得た実験結果をFig.10に示した。直径 $3.5 \mathrm{~mm}$ の水結晶の実験結果と同様，いずれの場合も見 かけ上, 表面付近で硫酸イオン濃度は高く, 中心付近で は低い。Fig. 6 で示したC 法による個々の水結晶の濃度 分布と比較して, 表面での濃度比が 2 倍近く高くなって いる。特に初濃度が低いほど見掛け上, 表面付近での濃 度比は高くなる傾向が見られた。このことは, 初濃度が 低いほど, 硫酸イオンは皮結晶の表面付近に偏在するこ とを示す。一般的には，ゆっくり水結晶を生成すれば低 濃度含有不純物は氷・水界面に押し出される。それ故, 直径 $18 \mathrm{~mm}$ の水結晶生成時にはより多くの硫酸イオンが 表面付近に集中する。

硫酸イオンの他に硝酸イオン, 塩化物イオンを同時に 含む氷結晶を A 法で溶解した場合の濃度変化を Fig.11

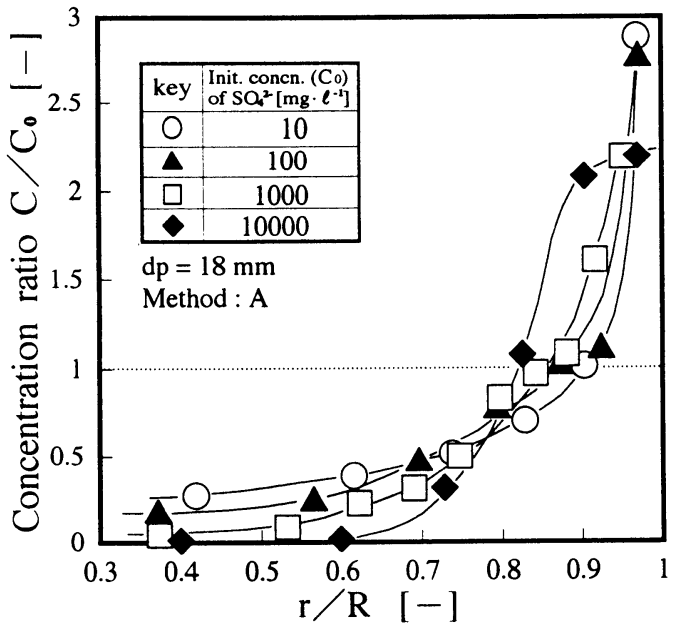

Fig. 10 Distribution of sulfate, dependence of initial concentration of sulfate ions

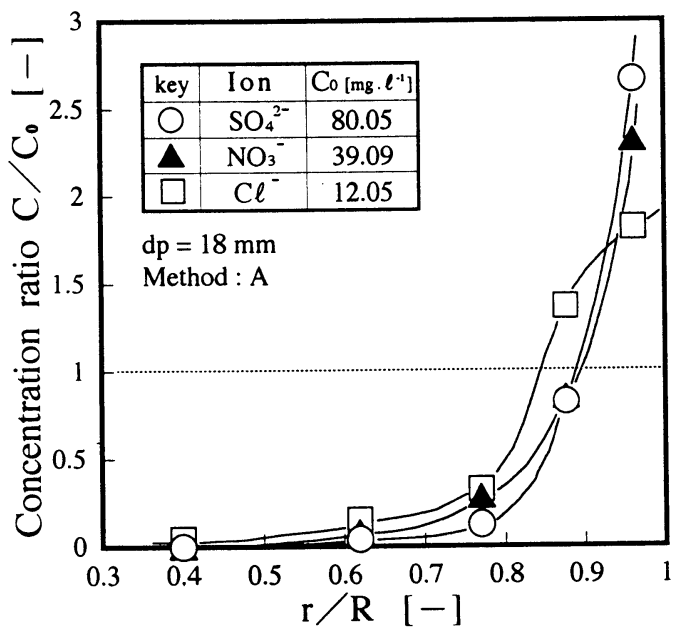

Fig. 11 Distributions of sulfate, nitrate and chloride ions

に示した。各イオンとも, Fig. 8 で示したC 法の結果と ほほ同様, 表面では濃度比は高く中心付近では低い結果 が得られた。硫酸, 硝酸イオンはほほ類似の濃度分布曲 線であったが, 詳細に見ると硫酸イオンは表面付近で硝 酸イオンよりも濃度比は高く, 中心付近では逆に低い值 となった。塩化物イオンは他の二成分と比較して表面付 近での濃度比は低い。溶解段階における各イオンの濃度 割合を三角線図で表し，Fig.12に示した。C法の結果と 同様, 溶解が進むにつれ塩化物イオンの割合が高くなっ た。溶出の順をつけると $\mathrm{SO}_{4}{ }^{2-}>\mathrm{NO}_{3}{ }^{-}>\mathrm{Cl}^{-}$であった。 この結果は, Blimblecombe らの報告 ${ }^{8)}$ と一致する。硫酸, 


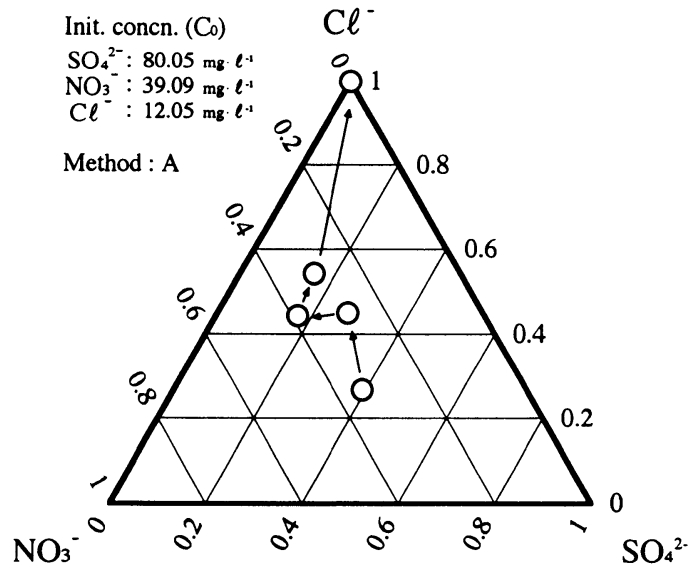

Fig. 12 Fractions of sulfate, nitrate and chloride ions

硝酸，塩化物イオン含有水結晶におけるイオン種間の溶 出の違いは, 塩化物, ナトリウム, マグネシウムイオン などは, 結晶水を伴った化合物として氷結晶中に残存で きるのに対して, 硫酸および硝酸イオンは, 硫酸 $\left(\mathrm{H}_{2} \mathrm{SO}_{4}\right)$, 硝酸 $\left(\mathrm{HNO}_{3}\right)$ およびアンモニア塩などとし て水相に溶解しやすいことが起因している7)。

\section{4 水柱中の漕度分布}

球状水結晶の表面付近に何故硫酸イオン濃度が高くな るのかを考察するために, 硫酸イオンを含む氷柱（円柱 状の水結晶）を生成し, 水柱中の硫酸イオンの濃度分布 を求めた一例を Fig.13に示した。硫酸イオンを含む溶 液を, 周囲を断熱したアクリル樹脂製円筒容器（直径 $1.5 \mathrm{~cm}$, 長さ $25 \mathrm{~cm})$ に入れ, 底をシリコン栓で封じ，下 部約 $1 \mathrm{~cm}$ を冷媒に浸し, 下部より徐々に凍結させ水柱 を生成した。生成後, シリコン栓を抜き, 容器から素早 く氷柱を取り出し, 氷柱を 5 つに分割し, ビーカー中で 室温で溶解した。初期に生成される水柱の下部ほど硫酸 イオン濃度が高い。氷結晶が生成する初期段階では多く の気泡が発生するが, 生成水柱中には中心付近で細長く, 下方に向かい円錐状に広がった気泡を取り込んだ白い氷 が観察された。

前野ら ${ }^{9)}$ は, 凍結面に溶存空気の過飽和が存在し, い わゆる等質核形成 (homogeneous nucleation) で気泡が 発生し，容易に水に捕捉されると述べている。不純物で ある硫酸イオンが存在する場合には凍結面で空気の過飽 和の状態下で異質核形成 (heterogeneous nucleation) の 役割を果たし, その結果気泡が発生するとも考えられる が, それは凍結 (氷結晶成長) 速度が数 $\mu \mathrm{m} / \mathrm{sec}$ と非常 に小さい場合の言及である。本実験では, 水結晶成長速

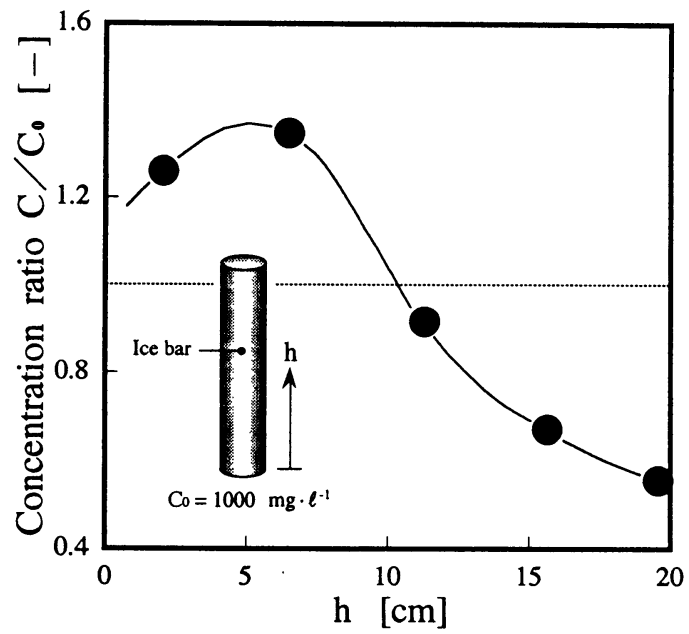

Fig. 13 Distribution of sulfate ions in an ice bar

度は比較的大きいことから，気泡がすべて溶存空気であ るとは考えにくく，3.2で述べたように主に氷結晶生成 時の急激な潜熱移動による水蒸気の気泡と考えるのが自 然である。

硫酸イオンの濃度分布と氷柱の生成過程の観察結果か ら, 白い部分すなわち気泡が存在する氷結晶成長界面付 近に硫酸イオンが多く濃縮されると考えられる。球状水 結晶の場合には, 球状水結晶は表面から凍結し, 白い表 面付近により多くの硫酸イオンが濃縮されると考えられ る。

\section{5 天然の雪について}

\section{5. 1 山間部の雪について}

新潟県湯沢高原でサンプリングした雪を山間部の雪と して用いた。雪はすでにザラメ雪の状態であった。約 $1.5 \mathrm{~m}$ の残雪中の上層, 中層, 下層に分けてその一部を サンプリングし, $\mathrm{pH}$ および硫酸, 硝酸, 塩化物の各イ オン濃度を調べた結果を Table 1 に示した。各イオン濃 度は, 下層ほど低くなっている。残雪量の多い4月末の 雪解け時には, 下層の雪は既に十分溶解・再結晶を繰り 返した後のザラメ雪である故，含まれていたイオン類は すでに大部分抜け出ている。それに比べて上層の雪は同 じザラメ雪でありながら下層の雪に比べ，溶解・再結晶 の繰り返し時間が短いためイオン濃度は相対的に高く なっていると思われる。

各イオンの濃度が一番高い上層部の雪を用い, A 法に よる溶解実験を行った結果をFig.14に示した。硫酸, 硝酸, 塩化物の各イオンの濃度分布は, 硫酸イオン単独 の場合とほほ同じ傾向の結果を得た。イオン種によって 濃度分布が多少異なるのは, 初濃度の違いによるものと 
Table 1 Some anions contained in granulared snow (Sampling place: Yuzawa Heights, April 21, '95)

\begin{tabular}{lcccc}
\hline & $\mathrm{p} \mathrm{H}$ & $\begin{array}{l}\mathrm{Cl}^{-} \\
{\left[\mathrm{mg} \cdot \ell^{-1}\right]}\end{array}$ & $\begin{array}{l}\mathrm{NO}_{3}{ }^{-} \\
{\left[\mathrm{mg} \cdot \ell^{-1}\right]}\end{array}$ & $\begin{array}{l}\mathrm{SO}_{4}{ }^{2-} \\
{\left[\mathrm{mg} \cdot \ell^{-1}\right]}\end{array}$ \\
\hline upper layer & 4.22 & 9.02 & 0.97 & 2.04 \\
middle layer & 5.12 & 1.44 & N.D. & 0.22 \\
lower layer & 4.72 & 0.86 & N.D. & 0.18 \\
\hline
\end{tabular}

Table 2 Some anions contained in granulared snow (Sampling place: Ikarashi Campus of Niigata Univ., Feb. 12, '96)

\begin{tabular}{cccc}
\hline p H & $\begin{array}{c}\mathrm{Cl}^{-} \\
{\left[\mathrm{mg} \cdot \ell^{-1}\right]}\end{array}$ & $\begin{array}{c}\mathrm{NO}_{3}^{-} \\
{\left[\mathrm{mg} \cdot \ell^{-1}\right]}\end{array}$ & $\begin{array}{c}\mathrm{SO}_{4}{ }^{2-} \\
{\left[\mathrm{mg} \cdot \ell^{-1}\right]}\end{array}$ \\
\hline 4.90 & 18.0 & 1.07 & 4.40 \\
\hline
\end{tabular}

推定される。

\section{5.2 海岸部の雪について}

新潟大学五十嵐キャンパス内でサンプリングした雪を 海岸部の雪として用いた。採取した雪はザラメ雪であっ た。 $\mathrm{pH}$ および硫酸，硝酸，塩化物の各イオン濃度を調 べた結果を Table 2 に示した。湯沢高原の雪と比較し, $\mathrm{pH}$, 各成分濃度ともに高い值であった。特に塩化物イ オン濃度は高く, 塩化物イオンはナトリウム, マグネシ ウムイオンなどと共に海塩の主成分であり，西高東低の 冬型の気圧配置による強い北西風で日本海上で雪結晶中 に混入し，その雪が海岸部に積もったためと思われる。

サンプリングした雪をA法によって溶解実験を行っ た結果をFig.15に示した。湯沢高原の山間部の雪と同 様に塩化物, 硝酸, 硫酸の各イオンの濃度分布は, 硫酸 イオン単独の場合とほぼ同じ傾向の曲線となった。

\section{4. まとめ}

硫酸イオンなどを含む溶液から生成した球状水結晶中 では, 球表面付近ほどそれらの濃度は高く，その溶液調 製時の濃度が高いほど濃度分布は一様に近づくことが判 明した。

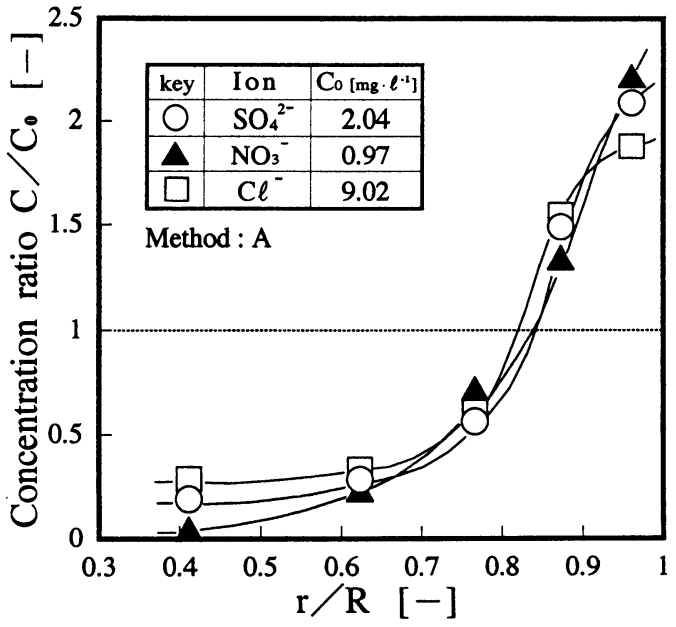

Fig. 14 Distributions of sulfate, nitrate and chloride ions in granular snow (Sampling place: Yuzawa Heights, upper layer, April '95)

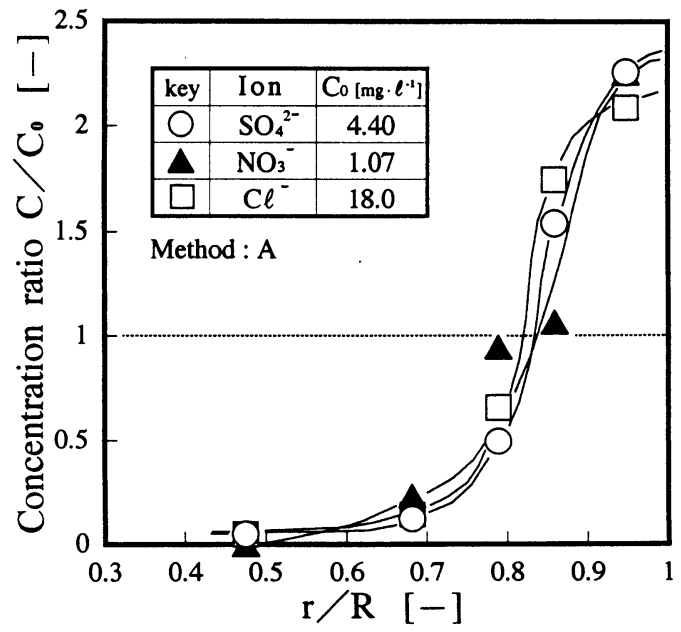

Fig. 15 Distributions of sulfate, nitrate and chloride ions in granular snow (Sampling place: Ikarashi Campus of Niigata Univ., Feb. '96)

水柱の生成・溶解実験から, 水結晶成長初期において 多くの気泡の発生が観察された。その気泡は氷結晶が生 成するときの潜熱移動に伴う水蒸気と推定され, 気泡の 共存する氷結晶成長界面付近に硫酸イオンなどの不純物 が集中することが確認された。

水結晶中の硫酸イオンの溶出の仕方は溶解方法によっ て異なった。自然の雪の溶解に近いA 法で溶解した場 合, 見かけ上, 球表面により多く偏在するように観察さ る。この理由として, 上からの溶解液が下部へ到達する 
までに溶解・再結晶を繰り返すことより濃縮が進行する と推定された。天然のザラメ雪中の硝酸イオン, 塩化物 イオンの場合も硫酸イオン単独の場合と同様の結果を得 た。

水結晶中の硫酸，硝酸，塩化物イオンの溶出のしやす さには違いが見られ，塩化物イオンが他のイオンに比べ 溶出しにくいことが判明した。これは, 天然のザラメ雪 の溶解実験においても同様であった。(化学工学会関東 支部新潟大会にて一部講演発表, 1995年 7 月28日）

\section{要 約}

春先の最初の雪解け水中の水素イオン濃度は高い傾向 にある。大気中を落下する雪は酸性物質を捕捉する。大 地に積もった新雪は, 圧縮され, 溶解と再結晶を繰り返 し, 氷状のザラメ雪となる。この繰り返しで, 硫酸, 硝 酸, 塩化物イオンは粒状ザラメ雪の表面に濃縮される。 硫酸イオンを含む溶液から球状結晶を生成し, それらを 溶解し，この濃縮現象を実験室的に検討した。

溶解実験により水結晶中の硫酸イオン濃度とその分布 を測定した。有機溶媒中で結晶を表面から溶解した場合, 硫酸イオンの分布は偏っていて, 表面付近により多く存 在した。結晶生成時の硫酸イオン濃度が高い程一様な分 布になる傾向にあることが分かった。

水結晶をカラム中に詰め室温でそれを溶解した場合, 最初の流出液中の硫酸イオン濃度が高いことを認めた。 又, その濃度比は有機溶媒を使用して得た球表面付近の 值よりも高くなった。ザラメ雪を溶解した場合, 同じよ うな結果が得られ, 最初の流出液中の硫酸イオン濃度は 後のものより高いことも分かった。

\section{文 献}

1) Massman, W. J.: Partitioning ozone fluxes to sparse grass and soil and the inferred resistences to dry deposition, Atmospheric Environment, 27A, No.2, 167-174 (1993)

2 ) Suzuki, K.: Chemical changes of snow cover by melting, Jap. J. Limnol., 43, 102-112 (1982)

3 ）日本規格協会：JIS K 0102, 「工場排水試験法」, pp143-146, 東京 (1993)

4 ) 前野紀一：「氷の科学」, pp98-102, 北海道大学図 書, 札幌 (1981)

5 ）木下誠一：「雪と氷の話」, pp72-76, 技報堂出版, 東京 (1988)

6 ）川崎成武：「工場操作シリーズー増補晶析 No.14」, 氷の結晶, pp187-194, 豊倉賢編, 化学工業社, 東 京 (1993)

7 ) Fukuzaki, N. and Ohizumi, T.: Movement and elution of chemical constituents in snowcover on the piedment of Mt. Myoko, Japan Soc. Air Pollut., 30, No.2, 92-103 (1995)

8 ) Brimblecombe, P., Clegg, S.L., Davies, T.D., Shooter, D. and Tranter, M.: Observations of the preferential loss of major ions from melting snow and laboratory ice, Wat. Res., 21, No.10, 1279-1286 (1987)

9 ) Maeno, N.: Air bubbles in ice, nucleated and trapped at an ice-water interface, Low Temperature Science, Ser. A, 24, 91-109 (1966) 